\title{
LITTERATURENS SPØRGEN
}

\section{Retorik og skrift i Blanchots litteraturfilosofi}

\section{CARsten Madsen}

Den franske forfatter og essayist Maurice Blanchot er lige siden begyndelsen af sit forfatterskab vendt tilbage til spørgsmålet om hvordan litteraturen er mulig, allerede den første essaysamling fra 1942 bærer dette navn, Comment la littérature est-elle possible? Ved således tilsyneladende at spørge til selve mulighedsbetingelsen for det man i andre sammenhænge beredvilligt accepterer som en gyldig diskurs, åbnes på én gang et transcendentalt felt og et ontologisk felt: litteraturen, finder den sin nødvendighed uden for det der er muligt at erfare i dens tekster? og er den som sådan konstitueret af væsensnødvendige træk, en bestemt væren? Litteraturen tages altså ikke for givet, den er ikke på forhånd defineret ved den måde hvorpå den deltager i diskurser, institutioner, læsninger eller andre funktioner. Blanchots litteraturfilosofiske arbejde er da også først og sidst mærket af bekræftelsen af litteraturens væsen som en mangel på væsen, et fravær af væsen der ikke er negativt bestemt. Det er denne mangel på væsen der for ham bringer litteraturen i spørgsmålets sted, her gives ingen svar, ingen garantier, og, litteraturens autenticitet opsøgt hinsides ufejlbarlighed eller sandhed, det litterære værk bliver fra nu af til som et åbent spørgsmål der endda går videre end en spørgen til spørgsmålets væsen. Alt synes i dette forfatterskab underordnet en stadig begyndelse der ikke gives nu, her, i værket, men i værkets forbindelse til et udenfor. · 


\section{Digtningens spørgsmål}

Blanchots begyndelser er fortsættelser, han genoptager et problem der er lige så gammelt som den litteratur vi kalder moderne. Formodentlig under inspiration fra Heideggers foredrag, „Wozu Dichter", 1 griber Blanchot tilbage til Hölderlins berømte spørgsmål fra elegien Brød og vin: „Wozu Dichter in dürftiger Zeit?" Digtets åbning af digtningens egen tvivlrådighed, betrængthed, er for Hölderlin forbundet med umuligheden af at få svar, idet spørgsmålet stilles dels ud fra antagelsen af at digtningen en gang i fortiden var gudernes sprog og dels i forlængelse af samme guders nuværende fravær. Digteren lader elegien stille ham selv dette spørgsmål uden at give digtningen eller nogen anden instans mulighed for at svare, han er fastholdt af spørgsmålet $\mathrm{i}$ et interregnum, en "overgangsfase", "et ubestemt sted mellem noget efterladt, ikke længere tilgængeligt helstøbt (græciteten) og noget uvist fremtidigt, der ikke lover nogen form for messiansk forløsning. "2 Skønt han intet steds siger det eksplicit, er Guds død - i filosofiens folkemunde dateret til omkring 1790 - for Blanchot en væsentlig begivenhed i den radikalisering af digtningen der har gjort det muligt at tale om en moderne litteratur. Guds død har da også været en afgørende erfaring for Hölderlin, idet fraværet af "Guds tale" i hans forståelse er forudsætningen for digterens tale. I påkaldelsen af det fraværende opstår det digteriske sprog hvori alle erfaringer er fremmede og gådefulde, verden må genskabes i digtningens imaginære billeder der rejser sig ud af den fordums gudssikrede men nu sammenstyrtede, ruinøse hob.

Hölderlins spørgsmål er altså især interessant ved dets forbindelse til en poetisk tid, en tid der nu, her, ingen fylde har, men som viser tilbage til en fortid befolket af guder, for dér at finde en mulig fremtid. Tiden i dag er knap, eller betrængt, både fordi guderne ikke længere er og fordi de endnu ikke er her. Dette dobbelte fravær ser Blanchot som en begyndelse, gudernes fravær er digtningens begyndelse, og hvis der er noget svar at finde på Hölderlins spørgsmål ligger det i spørgsmålet, dvs. i digtningen selv, hvor det i Brod og vin hedder at das Irrsal hilft. Vor henvisthed til i gudernes fravær at fejle, at gå vild, er også vort held, 
fordi digtningen her viser sig som udvej. I forlængelse heraf kalder Blanchot et andet dictum til vidne på den bekræftelse der kan ligge i en tarvelig tid: "Hölderlin siger ligeledes, i en variant af digtet "Dichterberuf", at udeblivelsen, Guds fravær, hjælper os: Gottes Fehl hilft."3 Dette er det afgørende træk i den tidligt-moderne digtning: et spørgsmål rettes i fortvivlelse til de fraværende guder i paradoksal forhåbning om anvisninger på verdens ordning i deres fravær. Selve spørgsmålet bliver derved sit eget svar, og vi ser direkte markeret i digtningen hvordan det krisebårne spørgsmål åbner sproget for at tale om en sprogløs omverden, der ikke længere er sikret den mening Gud kunne have givet den. Den anden strofe af "Hälfte des Lebens", en af Hölderlins Nachtgesänge, er meget tydelig på dette punkt: „Weh mir, wo nehm' ich, wenn / Es Winter ist, die Blumen, und wo / Den Sonnenschein, / Und Schatten der Erde? / Die Mauern stehn / Sprachlos und kalt, im winde / Klirren die Fahnen. " 4 Her. opstår digtningen ud af en sprogløs omverden ved at spørge til den og derved benægte den, et credo for digtningen magtfuldt understreget af sidste vers' fanfare, en kort smældende treklang med stor effekt intoneret af onomatopoietikonnet, "Klirren“. Spørgsmålet forbliver ubesvaret i den forstand at digtet efter interrogationen indfører et vindomblæst hus (hvis „Mauern“ læses som metonymi for et sådant) med en vejrfløj på taget, uden at dette hermetiske og enigmatiske billede kan siges at være motiveret af det foregående. Digtets billeder står i det hele taget parataktisk henkastede uden syntaks-medierende instanser, det inter-frastiske forhold er disjunktivt, som om alle konjunktioner, anaforer og andre koblingselementer var forsvundet med Guds død.

Den digteriske krisebevidsthed, der er skildret hos Hölderlin, er et tilbagevendende træk i moderne digtning, og vi finder spor af den overalt i splittelsesromantikken, i symbolismen, op igennem hele det nittende århundrede og langt ind i det tyvende. 5 Blanchot ser i forlængelse af Hölderlins „dürftiger Zeit" den moderne digtning som lukket inde i sin egen krise på én gang fremkaldt og udfriet af Guds fravær. Digteren føler sig ikke længere kaldet til at digte ud fra en tilskyndelse til at besynge, sådan som 
man siden Iliaden kunne sige at digtningen har fundet sin formelle anledning i det gudssikrede, Besyng, gudinde.... Fra og med Hölderlin finder digteren sit kald i en paradoksal form for inspiration: „i den inspiration der samtidig er mangel på inspiration og forbinder kreativ kraft og goldhed intimt med hinanden". 6

\section{Hvad er et spørgsmål?}

For at forstå litteraturens kritiske spørgen til sin egen mulighed og eksistens, hvilket også er en spørgen til forholdet mellem dens imaginære indebyrd og et eksistentielt erfaringsrum, må vi først forstå hvad det vil sige at stille et spørgsmål: hvad er et spørgsmål? Vi må først spørge til dette spørgsmål: „hvad er?“

Ethvert spørgsmål strukturerer formelt set sit eget svar, ja, det aftvinger måske netop utvetydige svar, med mindre det giver anledning til nye spørgsmål, men det ligger i spørgsmålets struktur at dets åbning af et sprogligt felt snart kan lukkes igen af et svar. Spørgsmålet er imidlertid i selve sin åbnende form, før svaret endnu vil have faldet, forbundet med en tilblivelse, sprog bliver til og udvikler sig ud af en spørgen. Derimod forbinder svaret sig ofte alt for hurtigt med en væren, især spørgsmålet „hvad er X?" venter utålmodigt på en beskrivelse af det værende for så vidt som det er. Svaret underordnes her uvilkårligt en værensproblematik, spørgsmålet afventer et svar af typen: "X er sådan og sådan beskaffen, $X$ har den og den væren!" Det ubestemt tilspurgte modtager en værensbestemmelse, det tilskrives en væren, et væsen og en sandhed. Men ikke nok med det, bestemmelsen, eller svaret, fastsætter nøje det ubestemtes sagsforhold inden for det bestemmeliges orden, uden at bestemmelsen selv er blevet påvirket af det ubestemtes gåde. Spørgsmålets åbenhed, hvor alt endnu var i sin tilblivelse, lukkes i svarets værensbestemmelse. I det ubesvarede spørgsmål kan alting altså først se ud til at være ubestemt, men for så vidt det strukturerer sit svar, som i eksemplet "hvad er X?" hvor der spørges til en væren, et væsen eller en substans, udstikkes det bestemmeliges rammer. Spørgsmålet kan endda selv udgøre bestemmelsen i en 
grad hvor det lukker sin formelle åbenhed: „skal du ikke snart i seng?" For så vidt svaret vil respektere spørgsmålets formelle åbenhed, kan man resummere problemet således: 1) spørgsmålet stiller en sag ubestemt, 2) det kan mere eller mindre strukturere det bestemmeliges rammer, 3) svaret sætter bestemmelsen inden for disse rammer, 4) men svaret kan endvidere reflektere bestemmelsen inden for de udstukne rammer. Bestemmelsen har gennem de udstukne rammer en defineret mulighedsbetingelse og ontologi som imidlertid gerne forbliver ureflekteret i svaret, hvorved det bestemmelige og det ubestemte kommer til at stå i et ydre forhold til hinanden. Først når bestemmelsen reflekterer sig selv i sammenpasningen af det bestemmelige og det ubestemte, kan man sige at svaret respekterer spørgsmålets åbenhed. Litteraturen er i sin spørgende form måske enestående ved netop at reflektere sine egne bestemmelser inden for den imaginære verden den samtidig fremstiller, hvorimod filosofien hele tiden begærer at fremstille en reel verden hvor alle bestemmelser, når de én gang er givne, ikke behøver nogen refleksion. Det er dette begær der hersker i spørgsmålet: "hvad er?"

Platon spørger gerne på denne måde: ti esti, hvad er? Spørgsmålet er hos ham netop aldrig åbent, det er ikke stillet på baggrund af en ikke-viden, men selve spørgsmålet forudsætter en viden og sætter derved betingelsen for, hvad der kan svares, en række mulige svar er givet i og med spørgsmålet. Når han fx lader den fremmede "søge at finde ud af, hvad en sofist er", ${ }^{7} \mathrm{er}$ svaret ikke kun bestemt af undersøgelsens forsøg på at skelne mellem sofisten, statsmanden og filosoffen, men også af selve dialogens maieutiske form. Den fremmede stiller sine spørgsmål på en måde hvor man må sige at han sammen med Theaitetos, dialogens anden part, driver en sand klapjagt på sofisten.

Heideggers radikale spørgen er derimod åben. Når han spørger til tingenes grund, lader han sig ikke nøje med at spørge til tingenes hvad-hed, deres beskaffenhed eller væsen, sådan som den husserlianske fænomenologi ser det som sin første opgave. Heidegger træder et skridt tilbage og spørger spidsfindigt til eksistensen, den at-hed der bestemmer hvordan vi taler om det mulige og det virkelige, tingens væsen og den eksistens der går 
forud for væsnet. Spidsfindigheden består i at han her erfarer at hans egen eksistens, det spørgende subjekt, er karakteristisk ved at forholde sig til den adspurgte tings væsen og eksistens på en særlig måde, hvilket for ham gør det nødvendigt først at spørge til Dasein, det at være til, tilværens Væren. Den egne eksistentielle og spørgende Væren er altså til forskel fra den adspurgte ting karakteristisk ved at have denne evne til at forholde sig, ikke blot til tingen, men også til sig selv som en Væren der sætter bestemmelsernes mulighed og virkelighed. Heidegger stiller sig ikke tilfreds med som Husserl at spørge til intentionaliteten eller rettetheden hos den spørgende bevidsthed. Problemet for Heidegger er her at Husserl netop ikke klart udreder forskellen mellem den adspurgte tings væsen og eksistens og det adspørgende Jegs væsen og eksistens, på trods af at Jegets Væren gennem sin spørgende adfærd må siges at være væsensforskelligt fra tingen. Husserls Jeg forbliver derved transcendentalt udhævet fra det adspurgte, Heideggers Jeg sætter sig selv på spil i sin spørgen. Gennem selve sin spørgen til Dasein må Jeget reflektere sine svars bestemmelser med samme åbnende ressourcer hvormed der spurgtes.

For Heidegger bliver det desuden stadigt klarere at hvis denne spørgen, der leder frem til en egentlig tilværensanalyse, ikke ligefrem er betinget af sproget, så er den i hvert fald bundet til eller forpligtet på sproget. Derfor må han også spørge til sprogets væsen: hvordan gør sproget det muligt at spørge til tilværens Væren? Ved at spørge på denne måde åbner Heidegger sproget, han lader sproget spørge sig selv: hvad er et spørgsmål? Men det svar han hører lyder således: ved at spørge får tilværen en bekræftelse på sin egen Væren, tilværen tiltaler sproget og får derved tilsagn om sin egen Væren. Heideggers spørgen til sprogets væsen har Jacques Derrida skematiseret på følgende måde:

I det øjeblik vi stiller det endegyldige spørgsmål, det vil sige når vi tilspørger [...] ethvert spørgsmåls mulighed, nemlig sproget, er det jo nødvendigt at vi allerede er i sprogets element. Det er jo således at sproget allerede taler for os - at det på en eller anden måde har talt og henvendt sig til os [...]. Anfrage og Nachfrage forudsætter dette forspring, denne sprogets forudgående (Zuspruch) tiltale. Den er der allerede, på 
forhånd (im voraus) i det øjeblik hvor ethvert spørgsmål kan udgå fra sit subjekt. Hvorved det går ud over spørgsmålet. Dette forspring er, før enhver kontrakt, en art tilsagn eller oprindelig alliance til hvilken vi så at sige allerede har samtykket, allerede har sagt $j a$, givet en pant, uanset negativiteten eller problematiciteten i den diskurs der kan følge deraf. ${ }^{8}$

Spørgsmålet involverer altså en bekræftelse, et tilsagn (Zusage) der $\mathrm{i}$ en vis forstand går forud for sproget, forud for en skelnen mellem bekræftelse og benægtelse, et ordløst Ja! der gør sproget til sprog.

Når Heidegger således spørger til sprogets væsen og derved i realiteten spørger til selve spørgsmålets mulighedsbetingelse, er det ikke mindst med henblik på at komme bag om mulighedsbetingelsernes konstitution i den moderne tænkning fra Descartes til Kant, bag om spørgsmålet: „hvad er oplysning?“ og de svar det fragter med sig, og bag om Husserls transcendentale subjekt. Die Aufklärung er hvad Blanchot ville kalde "en lykkelig periode", hvor "kun svarene synes at leve". "Men", som han tilføjer, „bekræftelsens lykke sygner snart hen. Det autentiske svar er spørgsmålets liv. [...] Et korrekt svar har sin rod i spørgsmålet. Det lever af spørgsmålet. " 9 Blanchot er her fuldstændig på linie med Heidegger, begge ser de nødvendigheden af ustandseligt at måtte begynde forfra, filosofien bliver til som en evig begynder, men også litteraturen, når den forsøger at skabe sig selv uafhængigt af den filosofi der allerede med Aristoteles har begrebet og programmeret den som mimesis, må begynde forfra: Hölderlins restaurerende begyndelse i græciteten, Mallarmés beklagelse over Homers store vildfarelse og henvisning til Orfeus som poesiens udgangspunkt.10 Til forskel fra Heidegger ser Blanchot imidlertid ikke en spørgen til sproget som knyttet til en eksistentiel erfaring, den samme spørgen åbner hos ham for en særegen litterær erfaring. De ville nok kunne være enige om, som Jacques Derrida siger det om Heidegger, at det er „i åbningen af dette Sprache at Dichter'ens og Denker'ens sprog krydses" (De l'esprit, p. 145), men for Blanchot vil digtningens sprog installere et eksistentielt fravær der gør det umuligt at tænke digtningen i værenskategorier. Blanchots spørgen til litteraturens mulighed 
markerer et radikalt brud med Heideggers værenstænkning, idet ethvert udsagn om en væren, $\mathrm{fx}$ i en optagethed af litteraturens mulige væsen, nødvendigvis må føre til en bekræftelse af tilværens Væren uden åbenhed for litteraturens særegenhed.

Blanchots spørgen til litteraturen viser altså ikke tilbage til Blanchot selv, forfatterens person, men er mere et udtryk for sprogets auto-dialog med sig selv. Han befolker således især sine dialogiske tekster i l'Entretien infini - men for så vidt også sine fragmentarisk disponerede tekster ( $l^{\prime}$ Amitié, le Pas au-délà og l'Écriture du désastre) - med fiktionære personer der.altid er spaltet $i$ to. Dette kommer tydeligst til udtryk i en lille dialog der står til sidst i en kursiveret og særskilt del af essayet „Le pont de bois (la répétition, le neutre)". Det ellers traditionelt opsatte essay 'fordobler' en romanbevægelse fra Don Quijote til Slottet tidligere optegnet af Marthe Robert i l'Ancien et le Nouveau; de Don Quichotte à Franz Kafka, men til sidst lader Blanchot sit essay bryde ud i denne lille dialog udhævet i citationstegn:

\section{[...]}

-Og hvorfor vil én enkelt talende, en enkelt tale, aldrig kunne nå frem til at sige navnet, selvom det kan se sådan ud? Der må mindst være to til at sige det.

- Jeg ved det. Det er nodvendigt at vi er to.

- Men hvorfor to? Hvorfor to taler for at sige én og den samme ting?

- Fordi det altid er den anden, der siger det (pp. 581-82).

I denne auto-dialogiske struktur af spørgsmạl og svar udspaltes der altså en svarende stemme fra den spørgende stemme. Blanchots essay reflekterer på denne måde sin egen spaltende fordobling, idet der her ikke er tale om en simpel spejling og uddifferentiering af essayets monologiske prosa $i$ to stemmer. $\mathrm{Og}$ der er heller ikke tale om en forestilling om at dialogen, som i romanen og allerede i Platons dialoger, er integreret i klart adskilte personer (Don Quijote og Sancho Panza, Sokrates og Menon). Spejlingen mellem spørgsmål og svar er derimod fordoblet i sig selv, altså en spaltning indefra, inde fra sproget selv, og ikke blot en udsigelsesbestemt spaltning som når Goljádkin møder sin dobbeltgænger. Det betyder, at når Blanchots skrift reflekterer sig selv, eller udspørger sig selv, er det ikke med henblik på en eller 
anden dialektik eller maieutik, der er ikke længere nogen forudeksisterende tanke eller idé der styrer og overvåger skriftens fremfærd. Blanchots skrift er en bestemmelse af skriftens mulighedsbetingelse og ontologi.

Blanchots hævdelse over for en traditionel dialektik mellem spørgsmål og svar er altså, at der findes et poetisk spørgsmål karakteriseret ved en fundamental åbenhed. Det poetiske spørgsmåls autenticitet er ikke bundet af muligheden for et sandt svar, det er bundet til det ikke-sande som ikke står i modsætning til det sande, og ikke lader sig jævnføre med løgnen, heller ikke som fiktionsbegreb, men måske netop i sit manglende engagement i sandheden udgør en væsentlig autenticitetsform. Men hvis det er tilfældet, spørger Blanchot, „kan vi så have noget værk? kan vi have kunst? På dette spørgsmål kan der ikke svares. Digtet er fraværet af svar. Digteren er en person der, gennem sit offer, holder spørgsmålet åbent i sit værk."11

\section{Den retoriske vending}

Blanchots poetiske spørgen bryder med ethvert forsøg på med sprog at beherske sproget. De retoriske, lingvistiske, grammatiske forsøg på at bestemme sproget søger ligesom at beherske det udefra. Blanchot er klar over at hans spørgsmål allerede er i sproget når han lader sin skrift udspørge det. Der er gået et tavst Ja! forud for sproget, og også dette Ja! tilhører sproget, men et sprog der er kvalificeret af sin mangel på sprogbruger. Derfor, siger Blanchot, vil autenticiteten i hans spørgen til sproget, til skriften, til litteraturen ikke omfatte ham, den poetiske spørgen udgør en suveræn litterær erfaring.

En sådan erfaring er en grænseerfaring; for den lader sig i fraværet af mennesket ikke uden videre indskrive i en eksistentiel erfaringsdimension. For Blanchot har den alligevel en historie, og det er denne litterære erfarings historie Blanchot skriver i sine mange essays om moderne litteratur og filosofi: Vi kan her forsøgsvist optegne visse konturer af denne erfarings historie.

De store moderne forfattere er måske netop dem der, omsider, ophørte med at tro på grammatikken, på samme måde som de 
store filosoffer efter Nietzsche ophørte med at forlade sig på dialektikken, på den menneskelige bevidsthed som en selvbeskrivelse med sig selv som udgangspunkt og slutmål. For dem begge, forfatterne og Nietzsche, gælder at de har måttet omstyrte en retorisk tradition, de har måttet vende sig mod de sproglige konventioner der per automatik syntes at garantere et meningsfuldt udsagn blot man fulgte de anvendte sproglige koders logisk-grammatiske regler. Indtil opgivelsen af sådanne regelsæt bekræftede man i tilliden til en klassisk retorisk tradition uafhjælpeligt enten en guddommelig kraft eller en subjektiv bevidsthed som udgangspunkt og slutmål for mennesket.

Nietzsche frygtede som bekendt, at vi ikke bliver af med Gud sålænge vi endnu tror på grammatikken, "folke-metafysikken" som han også kaldte den. ${ }^{12}$ Fordi den bevidste tænkning nødvendigvis må antage form af ord så Nietzsche sprogets og bevidsthedens udvikling som nøje forbundne, og han beklagede at menneskets individuelle eksistens gennem en sådan sproglig afhængighed reducerede sig selv til sin sociale natur: vor sprogligt betingede selvbevidsthed gør os gennemsnitlige. Hvor Hegel i Phänomenologie des Geistes havde set et åndeligt dyrerige som et nødvendigt gennemgangsled for fornuften i dens dialektiske udvikling mod en absolut ånd, dér talte Nietzsche i Die fröhliche Wissenschaft om at

den dyriske bevidstheds natur medfører, [...] at alt, hvad der bliver bevidst, af samme grund bliver fladt, tyndt, relativ-dumt, generelt, tegn, flokkendemærke; med enhver bevidstgørelse er der en stor og grundig fordærvelse, forfalskning, overfladiggørelse og generalisering forbundet. Til sidst bliver den voksende bevidsthed en fare; og den der lever blandt de mest bevidste europæere, ved ovenikøbet, at det er en sygdom (pp. 221-22).

Et sådant angreb mod den store bevidstgørelse af mennesket, der havde fundet sted fra Descartes til Hegel, søgte altså at løsne potentialer i menneskets individuelle eksistens, der ikke var bundet til bevidstheden og dermed til sproget, ikke engang bundet til et menneskeligt perspektiv. Nietzsche mente slet ikke, at 
bevidstheden tilhørte den individuelle eksistens, men snarere tilhørte menneskets sociale flok-natur.

Og vendt mod sin samtids retoriske tradition spørger han: „Hvem har indtil nu besiddet den mest overbevisende veltalenhed? Trommehvirvlen: og så længe kongerne har den i deres magt, vil de stadig være de bedste talere og folkeforfører" (§ 175, p. 144). Det vil sige at selv den mest formfuldendte veltalenhed og den højeste grad af bevidsthed intet vil kunne stille op mod det sprog der taler til menneskets primitivitet, til dets dyriske natur: derfor må mennesket overvindes. I denne vilje til at overvinde mennesket er der også en vilje til at overvinde det sprog der slår på trommer for at vi skal slutte op om en verden formidlet af logos, den sprogligt formidlede fornuft hvor sprog blot anvendes som et gennemsigtigt medium, en oversættelse af verden til bevidsthed. Følgelig søger Nietzsche også en musik, kunst og poesi der ikke er fastholdt af traditionens regelfaste, metriske rytmer, men i stedet hviler på pathos, uden at han dog ofrer bevidstheden og sproget for de rene passioner, tværtimod. Problemet for Nietzsche, hvad sproget angår, er dets reduktion til en simpel transitivitet: det forhold at sproget blot anvendes i en optagethed af hvad det omtaler, uden agtelse på hvordan og med hvilke passioner det bestemmer verden uden for sig selv. Nietzsche søger ikke en intellektuel forståelse af hvad der siges, men spørger altid hvem taler? "Hvem har indtil nu besiddet den mest overbevisende veltalenhed?" Med dette spørgsmål søger han at finde frem til passionerne, til den individuelle eksistens bag udsagnet, for således at læse hvilken vilje til magt der organiserer de givne udsagn.

Den ændring der her udvikler sig i den retoriske tradition finder sted $\mathrm{i}$ forholdet mellem regel eller efterligning på den ene side og stilen eller sprogbrugen på den anden (mellem præcepta og imitatio over for elocutio), idet sprogbrugen nu tildeles forrang i kreativitetens navn. Det medfører en generel ændring af retorikkens inventio-begreb, dvs. retorikkens udvælgelse af hvilket stof talen skal indeholde under hensyntagen til talens emne og publikums forståelse. En sådan ændring forudgribes i tidligromantikken, bl.a. i dens brug af en uendelig parabase der 
undergraver den mimesis eller imitatio som er grundlaget for den klassiske retorik. Men hos Nietzsche får inventio-begrebet afgørende ny status: „Det er tilstrækkeligt", som han siger, „at skabe nye navne, vurderinger og sandsynligheder for at skabe nye ting. [...] der ligger uendeligt meget mere $i$, hvad tingene hedder, end hvad de er" (§ 58, pp. 77-78). Det vil sige at han ikke stiller sig tilfreds med at skabe erkendelse ud fra klassiske topoi eller loci, det er for ham mindre et spørgsmål om „at udfinde eller opdage de centrale elementer i den foreliggende situation ", 13 men mere om at opfinde eller skabe nye navne og begreber. I et fragment af sit Nachlass fra 1885 skriver Nietzsche:

[Filosofferne] måikke længere blot lade sig skænke begreber, heller ikke kun rense og opklare dem, men derimod først og fremmest lave, skabe dem, fremstille dem og lade sig overtale til dem. Hidtil har man i det store hele fattet tillid til sine begreber, som en vidunderlig medgift fra en eller anden vidunderverden: men de er trods alt arven fra vore fjerneste, ligeså dummeste som klogeste forfædre. Denne fromhed mod, hvad vi finder $i$ os selv, er måske del af erkendelsens moralske element. Først og fremmest er den absolutte skepsis mod alle overleverede begreber nødven$\operatorname{dig}\left[\ldots . . .{ }^{14}\right.$

Den ændring der her er under udvikling er udtryk for en fjernelse af retorikken fra et fast grundlag, hvor det drejer sig om at bestemme tingenes væren, deres Idé, eller rettere sagt, hvor det drejer sig om at hypostasere tingene, frejdigt svare på spørgsmålet „hvad er?" og med det substansfikserende begreb fæstne tingene til et bestemt sted. Nietzsche søger en begrebsdannelse der bliver på tingenes overflade for at lade sproget deltage i den tilblivelse han mener tingene er underlagt. I kort begreb underordnes retorikken ikke længere en værenstænkning, men frisættes i en tilblivelsestænkning.

Men denne ændring findes ikke kun klart optegnet hos Nietzsche, benævnelsens skabende gestus er ikke kun et filosofisk anliggende. Effekterne fra en sådan retorisk ændring af måske især inventio-begrebet står klart at læse $i$ hans samtids moderne litteratur, ja, det er vel først og fremmest i den moderne lyrik man finder en mistillid til trivium, dvs. grammatikken, dialektikken 
og retorikken som tilstrækkeligt grundlag for skabelsen af litteraturens rent sproglige verden. Litteraturen har begribeligvis et andet forhold til sproget end filosofien, men alligevel synes det givtigt at parallelisere Nietzsche med samtidens rørelser i moderne digtning. Da Stéphane Mallarmé for hundrede år siden, i 1894, kom til Cambridge og Oxford for at forelæse om fransk poesi, åbnede han forelæsningen med disse ord: „Jeg bringer virkelig nyheder, af den mest forbavsende art, med mig. Et lignende tilfælde har man aldrig tidligere oplevet. Man har forgrebet sig på versemålet [On a touché au vers]. "15 Allerede i 1886 havde han skrevet en berømt opsats om "versemålets krise“, som han kaldte det. Men den revolution han gentagne gange bekræfter i det poetiske sprog er ikke eksplicit forbundet med opdagelsen af det frie versemål der vandt frem i fransk digtning i 1870-80'erne. For Mallarmé drejede det sig snarere om den komplicering af forholdet mellem poesi og prosa der fandt sted i prosadigtet. Efter at Baudelaire mere eller mindre havde opfundet denne besynderlige genre, eller ikke-genre, blev den en central digteform i frisættelsen af den digteriske kreativitet i slutningen af forrige århundrede.

Den moderne digtning bekræfter således en omstyrtning af den retoriske tradition, en omstyrtning der måske kommer tydeligst til udtryk netop i fransk prosadigtning, sådan som den udviklede sig fra Baudelaire til Rimbaud, Lautréamont og Mallarmé. Ikke blot er han en af de første registranter af denne ændring, men i sin egen digtning fuldender Mallarmé denne retoriske vending, sådan som også Nietzsche så nødvendigheden af det, en vending bort fra Ideerne om mennesket, bevidstheden, den metriske rytme osv. til fordel for frisættelsen af et sprog der bliver på overfladen af sin egen immanens og udvikler sig ifølge sine egne regler uafhængigt af Ideernes ledelse. Prosadigtets frisættelse af den digteriske kreativitet medførte således en bevægelse af litteraturens former mod det informelle, indtil modsætningen mellem poesi og prosa til sidst opløstes og gjorde plads for en opfattelse af litteratur som en skrift der kun tiener sit eget formål og ikke længere uden videre lader sig underordne retorikkens og stilistikkens begreber. I Les mots et les choses sam- 
menfatter Michel Foucault denne vending: „Til det nietzschianske spørgsmål: hvem taler? svarer Mallarmé, og gentager gang på gang sit svar, ved at sige at det der taler er i sin ensomhed, i sin skrøbelige svingning, i sin intethed ordet selv - ikke ordets mening, men dets gådefulde og usikre væren."16 Mallarmé er altså den digter, der endeligt bringer sproget ud over transitiviteten, som tidligere tillod dets umærkelige legering med bevidstheden. Med dette svars gestus indskriver han bestemmelsen som et aktivt reflekteret moment i sproget og giver det den åbenhed tilbage som spørgsmålet intonerede. Herved bliver han eksponent for en ny sprogbevidsthed der sætter ordets væren på spil, og man kan roligt sige at den moderne sprogtænkning Foucault, Derrida - er utænkelig og i et vist omfang uforståelig uden Nietzsche og Mallarmé.

\section{Litteraturfilosofiens epistemologi}

Det er utvivlsomt også ind i et sådant epistemologiske skred bort fra en subjektiv rationalitets dominans, i dens sammenhæng med en klassisk retorik, man skal forstå Maurice Blanchots litteraturfilosofi sådan som den kommer til udtryk $i$ hans essays. Interessen er her hele tiden dirigeret ind mod den rent sproglige væren uafhængigt af sprogets attributive struktur, dvs. uafhængigt af den Væren som sproget uvilkårligt synes at sætte sprogbrugeren i forbindelse med. Det er på dette afgørende punkt han bryder med den fænomenologiske tradition der måske kunne hævdes at være optaget af beslægtede problemer i forholdet mellem sprog, litteratur og Væren. Blanchot går længere end fænomenologien. Han bekræfter som den at sprogets rene væren bedst lader sig undersøge i litteraturen, men er samtidig fuldstændig klar over at en fænomenologisk metode er afskåret fra at bestemme dens væsen, idet litteraturens væsen for ham netop er at den intet væsen har. Derfor udvikler hans litteraturfilosofi sig også som en række intrigante paradokser, når tænkningen mener at have overstået sproget bliver han stående ved de problemer og paradoksier i sproget som fænomenologien hjælper ham til at synliggøre. 
For Blanchot bekræfter Mallarmé og Nietzsche, hver på deres måde, en grænse-erfaring, eller galskab, der er forbundet med selve skrivehandlingen. Hvis man i kort begreb skulle uddrage originaliteten og konstansen i dette litteraturfilosofiske arbejde, måtte det dreje sig om erfaringerne forbundet med selve dette at skrive. Blanchot udvikler på baggrund af skrive-erfaringen en forståelse for sproget som en betydningsforandrende produktivitet som sprogbrugeren er indskrevet $i$, endnu før han bringer sproget $\mathrm{i}$ anvendelse. I sin læsning af den moderne litteratur spørger Blanchot derfor aldrig om hvad dette digt eller denne roman betyder, men altid om hvordan skriften erindrer om den skrivehandling der gik forud. Han søger således at reflektere skribentens skrivehandling som en essentiel aktivitet, en produktivitet der forsvinder i skriften. Den generelle og implicitte hævdelse i denne tænkning over litteraturens væsen er altså, at i selve processen af at skrive bliver skrivehandlingens begivenhed fraværende i skriften, og den litterære skrift er her særegen ved at nære sig ved det fravær skrivehandlingen ustandseligt stødes ud i. Da skrivehandlingen (eller slet og ret, skriven) kun er markeret gennem sit fravær, efter at den er blevet til skrift, kan man heller ikke sige at skribenten er til stede i skriften gennem sin skriven. Denne skriven kendes kun gennem sine effekter på skriften. Skriver skribenten passioneret om sit emne er det ikke hans passioner, men derimod skriftens egen modtagelighed for passioner der bliver udtrykkelige i skriften. Den frembringelse af betydning der gør skrift til litteratur lykkes altså kun for så vidt skrivehandlingens pathos forsvinder i skriften, eller i det omfang forfatteren formår at få sin egen stemme til at tie. Kun derved kan skriften rumme pathos.

I det indledende essay fra l'Espace littéraire, "La solitude essentielle", beskriver Blanchot sit litterære ideal som et nøgent sprog. Hermed menes der et sprog hvis autenticitet ikke beror på "dets stil eller sprogets interesse eller kvalitet", et sprog hvor det tonefald der karakteriserer teksten ,ikke er forfatterens stemme, men den tavshedens intimitet som han pånøder sproget, hvilket gør at denne tavshed stadig er hans egen, og som er det der bliver tilbage af ham selv i den diskretion der tilsidesætter ham. Tone- 
faldet skaber store forfattere, men måske værket ikke bekymrer sig om hvad der gør dem store“. ${ }^{17}$ Forfatterens stemme er altså den stemme der endnu tilhører verden, som vi kender den før vi træder ind i litteraturens univers. Men på vejen ind i værket "drages skribenten mod" sin egen „udviskning”, som det videre hedder, for at sproget $i$ fraværet af forfatteren og hans verden, $i$ den tavshed hvormed han er til stede i værket, kan åbne sig i en selvudfoldelse der bekræfter sproget som litteratur, hvilket for Blanchot vil sige fravær af verden. Det nøgne sprog som Blanchot således opstiller som et ideal, og som man kender for eksempel fra Kafka, Blanchots egne fortællinger og folkene omkring og i udkanten af le nouveau roman, søger altså at udviske alle personlige træk ved stilen. Det betyder, at han søger et litterært sprog der ikke som i den klassiske retorik formes med henblik på at vække bestemte følelser som fornuften derefter kan forholde sig bedømmende til. Stilen, eller det retorikken kalder elocutio, læren om hvordan man former de tanker man vil udtrykke, underordnes et andet hensyn end i den bevidste tilrettelæggelse af sproget. Dette nøgne sprog frisættes $i$ et vist omfang fra bevidstheden og underordnes skriftens egne immanente regler, sådan som de udvikler sig i processen af at skrive. Idet det litterære værk er i færd med at blive til, pånøder det sin forfatter en række form-krav som bliver styrende i den kreative proces, og på denne måde bliver skrivehandlingen hele tiden underordnet skriften. Ved således at overlade sproget til sig selv søger Blanchot betingelserne for en særegen erfaringsform på rent litterære vilkår. Den litterære erfaring han tegner et billede af er altså bundet til en skrift der bliver til ved at pånøde sin forfatter en tavshed. Kun i denne tavshed kan ordets "gådefulde og usikre væren" tale, som det hedder hos Foucault.

Således kan man også sige at Blanchot ikke levner plads til en subjektsforestilling som udgangspunkt for en forståelse af den moderne litteratur. Ved at læse litteraturen som en spænding mellem skriven og skrift opgiver han hele den fænomenologiske bevidsthedsdimension der.var styrende for fyrrernes og halvtredsernes litteraturdebat i den franske eksistentialismes forestilling om en engageret litteratur og i la nouvelle critique. På denne 
måde kunne man endvidere sige at han forudgriber strukturalismen, men mere interessant er utvivlsomt hans medvirken i sammensæiningen af den kanon af moderne forfattere der gør sig gældende i fransk litteraturkritik, - mere interessant fordi den endnu i dag kan siges at være medbestemmende for vort syn på den moderne litteraturhistorie. Blanchot bekræfter gentagne gange sporene efter skrivehandlingen i den litterære skrivemåde sådan som den udvikler sig fra Hölderlin og de Sade over Flaubert, Mallarmé, Lautréamont og Nietzsche til James, Proust, Rilke, Kafka, René Char, de franske surrealister, Artaud og Duras.

Blanchots essays er særegne ved at bygge bro mellem filosofi og litteratur uden hverken at ofre sandheden til fordel for fiktionen eller omvendt. Ganske vist tager han parti for litteraturen, men det er han nødt til for overhovedet at agte på den, spørgende at træde ind i den. Filosofiens problem har altid været at den ikke rigtig har kunnet agte litteraturen eller ligefrem har følt sig truet af den, hvorfor filosofi langt hen har udformet sig som beherskelse når den har forholdt sig til den skrift den begrebsliggør med ordet litteratur. Dette synes at have været tilfældet lige fra filosofiens start.18 Men det må være klart at en sådan tænkning, der forstår mennesket som essentielt indskrevet $\mathrm{i}$ et betydningsunivers større end mennesket selv, må gå til litteraturen hvis den vil vide mere. Den litteratur der siden Mallarmé har udviklet sig ud fra en optagethed af ordets væren har forbindelse til noget uden for mennesket og for så vidt noget utænkeligt som en konstituent for tanken og eksistensen. I fransk åndsliv har man ikke kun en tradition for at filosofien går til litteraturen, men også for at litteraturen tager filosofiens problemer på sig. Blanchot har måske mere end nogen anden forfatter indskrevet sig $i$ denne tradition, og det er derfor heller ikke overraskende, at man i tressernes franske tænkning i stigende grad konsulterede Blanchot, her kunne man finde en erfaringsform bundet til skriften uafhængigt af mennesket bag skriften. Især Foucaults tænkning bliver i første halvdel af tresserne præget af Blanchot, ${ }^{19}$ men også Lyotard, Deleuze og Derrida anerkender en arv fra Blanchot.

Til bestemmelsen af det epistemologiske brud, som Blanchot således indskriver sig i og desuden er en af de skarpeste iagtta- 
gere af, kan her anføres endnu et par citater af Foucault. Fra og med det nittende århundrede, skriver Foucault i Les mots et les choses,

fjerner litteraturen sig mere og mere fra ideernes diskurs, og spærrer sig inde i en radikal intransitivitet; den løsner sig fra alle de værdier der i klassikken fik den til at cirkulere (smagen, lysten, det naturlige, det sande), og i sit eget rum fremkalder litteraturen alt det der gør den til en legende benægtelse (det skandaløse, det hæslige, det umulige); den bryder med enhver "genre"-definition som former tilpasset en repræsentationsorden, og bliver ren og skær manifestation af et sprog hvis eneste. lov -i modsætning til alle andre diskurser - er at bekræfte sin egen brydsomme eksistens; den er således henvist til at bøje sig i en stadig genkomst om sig selv, som om dens diskurs ikke kunne have andet indhold end at udsige sin egen form: litteraturen henvender sig til sig selv som skrivende subjektivitet, eller den søger, i bevægelsen af det der fremkalder den, at gribe essensen af al litteratur; og således peger alle dens tråde ind mod det fineste tænkelige punkt - på en gang singulært, øjeblikkeligt og universelt - ind mod selve skrivehandlingen. I det øjeblik hvor sproget, som almindelig sprogbrug, bliver til et vidensobjekt, da genopstår det i en fuldstændig modsat modalitet: en tavs, omhyggelig overgivelse af ordet til forvaring på papirets hvidhed, hvor det hverken kan have nogen klang eller deltage i nogen samtale, hvor det ikke har andet at sige end sig selv, intet andet at fortage sig end at tindre i sin værens funklen. (p. 313).

Foucaults bestemmelser af den moderne litteratur skatter her ikke kun til Mallarmé, som han umiddelbart inden dette citatsted henviser til, men også til Blanchot der fremskriver samme erfaring. Men ved således i ekstrem grad at koncentrere sine betydningspotentialer om sig selv, ved i en selvhenvisning at lade sprogets tegn reflektere sig selv, kunne man forledes til at tro, at litteraturen herved bekræfter den autonomi hvormed man i begyndelsen af forrige århundrede bestemte den moderne, romantiske digtning som l'art pour l'art. Den litterære skrift der opstår i denne selvhenvisning er imidlertid ikke i egentlig forstand udtryk for at skriften indvendiggør sig. I artiklen „La pensée du dehors", skrevet til et særnummer om Blanchot af tidsskriftet Critique som han sammen med Bataille var medstifter af, imødegår Foucault denne kritik der med jævne mellemrum 
har været rejst over for den litteratur man har opfattet som urimelig hermetisk, vanskelig tilgængelig. Når litteraturen koncentrerer sine udtrykspotentialer om ordets egen væren, betyder det ikke at den lukker sig inde i sig selv,

det drejer sig i langt højere grad om [at finde] en passage til et "udenfor": sproget unddrager sig diskursens væremåde - dvs. repræsentationens dynasti -, og den litterære sprogbrug udvikler sig fra sig selv, idet den danner et net hvor hvert enkelt punkt, der er klart adskilt fra de andre og er på afstand af selv de mest nærliggende, er anbragt i forhold til alt $i$ et rum der $p a ̊$ en gang rummer dem og adskiller dem. Litteraturen er ikke et sprog der bringer sig nærmere sig selv indtil punktet af sin brændende manifestation, den er et sprog der placerer sig fjernest fra sig selv; og hvis den i denne gøren sig "ude af sig selv" afslører sin egen væren, da åbenbarer denne pludselige klarhed snarere en forskel end en fold, en spredning snarere end en tegnenes ransagen sig selv. ${ }^{20}$

I disse sammenstillede citater er det vigtigt at fastholde den skrivehandling, som også Foucault mener karakteristisk for den moderne litteraturs betydningsdannelse. Alle litteraturens tråde peger ind mod det punkt eller det øjeblik hvor dens tekster bliver til og med en suveræn gestus afsluttes. Selve det øjeblik hvor forfatteren trækker sig endegyldigt tilbage fra sin tekst for at overlade den til læseren, hvor han kan sige at den er et fait accompli, dette øjeblik er skrivehandlingens forsvindingspunkt, og det er gennem det punkt teksten står i forbindelse med et udenfor hvorfra den modtager al sin udtrykskraft. Det er fristende at forstå dette udenfor som verden eller virkeligheden, men det er netop en sådan bestemmelse Blanchot undgår, fordi den forflygtiger forståelsen af litteratur som en sproglig relation til det udenfor, det der er længere væk eller tættere på end enhver verden.

\section{Hvordan bliver sprog til?}

Vi så tidligere at Blanchot søger at forstå den litterære skrift uafhængigt af en sprogbruger, at han vil forbinde sproget med en 
essentiel anonymitet. Men hvor kommer sproget så fra, og hvad kan vi sige om dets fremtrædelsesform i vort eget fravær?

I Blanchots optik mister sproget hurtigt den kohærens og meningsfuldhed vi i dagligdagen tildeler det, og vi er derfor kun levnet den mulighed at bestemme det som fragmentarisk. Om et sådant fragmentarisk sprog skriver Blanchot i essayet „Nietzsche et l'écriture fragmentaire", et i sig selv fragmentarisk disponeret essay:

„en fragmentarisk tale er på grænsen til ikke at være tale. Det betyder ikke at den kun taler ved talens ende, men at den til enhver tid følges med og løber igennem enhver form for viden og diskurs med et andet sprog der afbryder talen ved i skikkelse af en fordobling at lokke den mod et udenfor, hvor det uafbrudte taler, den ende der aldrig ender" ${ }^{\prime 21}$

Hævdelsen er at der eksisterer et ubestemmeligt sprog før eller under dagligdagens kohærente og meningsfulde sprog. Dette "andet sprog" fremtræder i dets afbrydelse af dagligsproget som fragmentarisk, men i realiteten udgør det en uendelig talestrøm. Bestemmelsen af et sådant sprog må nødvendigvis vurdere hvordan den selv er underlagt dets særegne logik, hvilket naturligvis kun kan give anledning til paradokser i den bestemmende diskurs. Hvis man forsøgsvist (i et alt for diskursivt sprog) skulle angive indsatserne $\mathrm{i}$ dette projekt, kunne man imidlertid med fordel parallelisere Blanchots ærinde med den fænomenologi han fører en tæt dialog med.

Blanchot tager udgangspunkt $i$ at det litterære sprog bliver til i fraværet af verden, alt hvad dette sprog omtaler holder det ind $i$ en essentiel negativitet, en intethed. Negativiteten i litteraturens sprog må forstås som væsensforskellig fra en filosofisk negativitet eller negation, en filosofisk negation falder ind under dialektikkens og dermed bevidsthedens herredømme. Ligesom den franske fænomenolog Merleau-Ponty problematiserer han i forbindelse med det cartesianske cogito at diskursens konkrete verden, der understøtter og betinger et "cogito, ergo sum”, ikke spiller nogen rolle for Descartes, at tænkningen glemmer sproget. I Phénoménologie de la perception (1945) fremholder Merleau-Ponty 
over for Descartes at ikke kun må et cogito være betinget af den tale der siger: „jeg tænker“, men denne tale, der udsiger cogito'et, kommer desuden til udtryk på baggrund af en tilstand som Merleau-Ponty forstår som et tavst og præ-refleksivt cogito. Tænkningen får form $i$ et sprog og i en historie der bliver fraværende i det talte cogitos rene intelligibilitet, hvorfor MerleauPonty også sidenhen, i Le visible et l'invisible (1964), forsøger at nå bag om det tavse cogito for at finde meningens oprindelse i en rå, uforarbejdet Væren. Kritisk vendt mod denne fænomenologis prioritering af det uudsigeligt sprogløse som sandhedens sted argumenterer Blanchot at der må gå et sprog forud for en hvilken som helst tale om et cogito, også et tavst cogito der jo endnu er afhængigt af at blive bekræftet i sproget, og netop derfor også forud for Væren.

Blanchot vender sig dernæst mod fænomenologiens privilegering af synssansen og dens forståelse af sproget som en sammenknytning af Væren, mening og lys. For ham er negativiteten i det litterære sprog en bortvendthed fra lyset, fra fornuftens strålende rige. Sammenknytning af Væren, mening og lys kommer bl.a. til udtryk når Heidegger i Hvad er metafysik taler om lyset fra Væren som erkendelsens grund. Argumentet går her at et lys fra Væren, eller "Værens lysning“, belyser det værende, dvs. de ting vi således bliver i stand til at erkende, men samtidig skjuler disse ting lyset fra Væren, som vi derfor ikke får øje på. I den danske oversættelse tilføjer Jørgen Hass:

I forhold til det værende er Væren som lyset ("Licht“) til tingenes udseende. Erkendelse er op-lysningen ("die Erhellung") af det værende. Erkendelsen er det syn (,Sicht"), udsyn (,Hinsicht") eller blik, som afdækkes af lyset. Lyset (Væren) muliggør udsynet og tingenes udseende (erkendelsen og det værende), men er ikke selv en værende genstand. ${ }^{22}$

Blanchot hævder altså heroverfor at der må gå et sprog forud for Væren, forud for hvilket som helst cogito. Dette forudgående sprog er for Blanchot helt neutralt, dets tale er en "neutral“ stemme, en mumlende baggrundsstøj, forud for Heideggers Dasein eller det cartesianske cogito. I essayet "Den narrative Stemme" 
fra l'Entretien infini skriver Blanchot i bestemmelsen af et sådant forudgående sprog, at det neutrale ord „ikke giver mening på samme måde som det synlige-usynlige giver mening, men at det åbner en anden egenskab i sproget som er fremmed for evnen til oplysning (eller formørkelse), til forståelse (eller misforståelse). Det giver ikke mening på en optisk måde; det forbliver uden for den lys-skygge henvisning der synes at være den yderste referent for al viden og kommunikation, så den til sidst får os til at glemme at dens eneste værdi er at være en ærværdig, det vil sige indgroet metafor." 23

Blanchots kritik af fænomenologiens sprogopfattelse kan endvidere ses i forlængelse af hans forståelse af den indre forskel i skriften mellem den skrivehandling der gik forud og skriften selv. Han opfatter således den litterære skrift som udtryksformer der gør sig uafhængig af et Jeg, det der taler er en upersonlighed, en sprogets neutrale og anonyme Han. Den litterære erfarings særlige form er for så vidt uløselig bundet til den skrift hvori den fremstilles. Dens bestemmelser, af sproget, ja, endda af Livet, finder kun sted $i$ en refleksion af bestemmelsens mulighedsbetingelse og ontologi, i den åbenhed der tilhører et spørgsmàl. Skriven erindrer om de spørgsmål der blev stillet til skriften, men i skriften manifesterer skriven sig kun gennem sine effekter, alt mens skriften uafhjælpeligt støder erfaringsøjeblikket ud i et fravær. Skrivens fravær lader sig dog ikke bestemme gennem et (nyt) nærvær i skriften, men dens vedblivende fravær i skriveprocessen får betydning for oplevelsen af det færdige resultat, idet det litterære kunstværk nu fordrer at blive læst på andre betingelser end de traditionelle. ${ }^{24}$

\section{Skriftens figurer}

Blanchots essays bliver gerne til i en gennemskrivning af et filosofisk problemkompleks, men han vender den oprindelige problematik om og gør den til en tænkemaskine i litteraturens tjeneste. Det er her man finder en bevidst udnyttelse af en retoriske vending eller forskydning. Han forskyder fx Heideggers omsorg for eksistensen, for Dasein, og forsøger at iagttage hvordan litte- 
raturen drager omsorg for sproget. Derfor går han også gerne i dialog med filosofi der overvejer sprogets erkendelsesteoretiske status, men forskyder eller skævvrider dernæst den filosofiske argumentationskæde, idet han fuldstændig sætter den i sprogets tjeneste og fjerner den fra dens intentionalitet. Selve essaystikkens form reflekterer herved det litterære sprogs alternativ til en fænomenologisk bevidsthedsdimension. Man finder således i hans essays en hæmningsløs brug af filosofemer, mytologismer og litterære loci, der hver gang indgår i Blanchots særegne sammenhæng, som om der var tale om et locus classicus, som i den klassiske retoriks inventio, men som imidlertid først fremstår med prægnans i den nye sammenhæng han installerer dem i, næsten som om de var skrevet for ham at reflektere over. Denne forskydningslogik gør hans essays ganske unikke ved at lade dem svinge i et udefineret område mellem et filosofisk og et litterært sprog, og den understreger desuden sprogets anonymitet, idet mange af disse figurer ikke forsynes med henvisninger. Han gennemskriver således gentagne gange motiver fra Hegels dialektik, Husserls fænomenologi og Heideggers eksistensfilosofi og bearbejder mytologiske figurer som Orfeus, Odysseus, Lazarus osv.

Et eksempel på de filosofiske motiver, som Blanchot frit tilpasser refleksionen over litteratur, kunne være den sætning han fire gange iscenesætter i essayet „Litteraturen og retten til døden" fra la Part du feu, en sætning forsynet med citationstegn, men ikke nogen reference. Denne sætning lyder: „livet tåler døden og bevarer sig selv i den". Kun den læser der er fortrolig med "Vorrede" til Hegels Phänomenologie des Geistes erindrer at sætningen er fjernet herfra, ovenikøbet i en for Hegel bestemt strategisk sammenhæng hvor han bestemmer subjektet som "den sande substans, Væren eller den umiddelbarhed, som ikke har mediationen uden for sig, men er denne mediation selv. “25 Man kan sige at Blanchot har grebet ind i det allermest sårbare sted i Hegels argumentationskæde, idet den medierende status subjektet her tildeles næppe er overbevisende fremstillet, men typisk for Blanchot bruger han udelukkende sætningen til sit eget formål i bestemmelsen af sprogets essentielle negativitet, og 
sidste gang den citeres hedder det, at det er sproget der er "livet der tåler doden og bevarer sig selv $i$ den". Et eksempel fra samme essay på et litterært locus classicus, som han reflekterer over, kunne være følgende sætning: „Jeg siger: denne kvinde, og hun er umiddelbart tilgængelig for mig, jeg bringer hende på afstand, jeg bringer hende nær, hun er alt, hvad jeg ønsker, at hun skal være, hun bliver stedet for de mest overraskende forvandlinger og handlinger: ordet er livets lethed og sikkerhed." Også denne sætning står uden reference, men er tydeligvis et lån fra Mallarmés berømte sætning: „Jeg siger: en blomst! og, ud af den glemsel hvor min stemme forviser enhver kontur, for så vidt som den er noget andet end de kendte blomsterbægre, rejser sig musikalsk, selve den milde idé, den i alle buketter fraværende."26 Hele dette essay er desuden en implicit kommentar til Sartres essay Qu'est-ce que la littérature? der udkom i 1947, året før første halvdel af "Litteraturen og retten til døden" udkom i et tidsskrift, i øvrigt under titlen „Det åndelige dyrerige“, en ny implicit henvisning til Hegels Phänomenologie des Geistes.

Disse figurer og lån af forskellig art skal imidlertid ikke forstås som allegorier, sådan som det har været' hævdet.27 Blanchot forsøger ikke at sige noget andet end det han faktisk siger. Den klassiske allegori har „en dobbelt betydning, en bogstavelig og en overført betydning, hvormed man præsenterer en tanke i billedet af en anden tanke, der er velegent til at skabe større fornemmelse for den og gøre den mere slående, end hvis den blev præsenteret direkte og uden nogen form for slør. “28 I et essay kaldet „Mødet med det imaginære" fra le Livre à venir går Blanchot $\mathrm{i}$ direkte polemik mod en sådan allegorisk bestemmelse af skriftens figurer. Han anvender her historien om Odysseus' møde med Sirenerne som en mytologisme der hjælper ham til at formulere de betingelser en fortælling bliver til under, og det hedder bl.a.: „En fortælling er ikke et referat af en begivenhed, men den er selve begivenheden, tilnærmelsen til begivenheden, det sted hvor netop denne begivenhed er bestemt til at indtræffe, en endnu fremtidig begivenhed og gennem hvis tillokkende kraft, fortællingen kan håbe på, at også den virkeliggøres. " Det hedder videre: „At lytte til Sirenernes Sang er det samme som at ophøre 
med at være Odysseus og blive Homer, men det er imidlertid kun i Homers fortælling at det virkelige møde fuldbyrdes hvor Odysseus bliver til den der kommer i forbindelse med elementernes rasen og afgrundens stemme." Og videre: „[Sirenerne] lokkede [Odysseus] hen til et sted hvor han ikke havde til hensigt at gå til grunde, og skjult i det indre af Odysseen, der blev deres grav, drev de ham sammen med mange andre ud på den lykkelige, ulykkelige sejlads som er fortællingens sejlads." "Dette“, fastslår Blanchot, „er ikke en allegori." 29

Når denne mytologisme ikke er en allegori, eller fx en parabel, skyldes det at figuren bliver en demonstration af sit eget udsagn. Idet essayet revokerer fortællingen om Odysseus og Sirenerne, indgår den som en del af essayets egen tilblivelse hvor fortællingens betingelser udfolder sig. Ligesom Odysseus ifølge Blanchot bliver til Homer i og med fortællingen fortælles, bliver Homer til Blanchot i og med figuren installeres i denne nye sammenhæng. Essayet er således mærket af det fortællemæssige træk det samtidig bestemmer, og Blanchots figurer må derfor forstås rent bogstaveligt. Inden for den klassiske retorik kunne man sige at hans figurer fungerer som allegorismer snarere end som allegorier, dvs. figurer der fordobler og forskyder allegoriens figurer. Allegorismen er en „forlænget og fortsat metafor der, selv når den udvides til at omfatte hele sætningen, kun lader en enkelt mening finde sted, og som da kun tilbyder tanken et enkelt objekt. "30 Allegorismen låner altså sine trræk fra allegorien, men berøver den samtidig dens overførte, figurerede betydning. Det betyder, at den litterære erfaring Blanchot gør rede for står og falder med selve redegørelsen, den findes kun i den bevægelse essayet gennemskriver. Således mister skriftens figurer deres figurerede betydning og antager bogstavelighedens skikkelse i takt med at erfaringen bevæges væk fra et eksistentielt anliggende og bliver til på de litterære præmisser der samtidig oparbejdes.

Generelt kan man sige at disse figurer, der i den traditionelle retorik hører under inventio, hos Blanchot underordnes en systematisk tilblivelsestænkning der, som vi så hos Nietzsche, giver kreativiteten forrang og derved tillader ham at opfinde stadig nye bestemmelser af litteraturens væsensløse væsen. Anven- 
delsen af figurerne $i$ en sådan tilblivelsesproces er karakteristisk for Blanchot og indgår $i$ den generelle strategi hvormed han søger at bringe læsningens opmærksomhed hen på skrivehandlingen som konstituent i skriften.

\section{Læsningen af neutralitetens pathos}

Blanchots stædige udspørgen af litteraturen giver ingen positive, etiske svar, men henviser mennesket til et negativt univers. I "Ars nova" fra l'Entretien infini spørger han: „er mennesket modtageligt for en radikal spørgen, hvilket i sidste instans vil sige: er mennesket modtageligt for litteratur, når litteraturen vender sig mod bogens fravær" (p. 514/p. 169)? Litteraturens spørgen reflekteres her, naturligt nok, i spørgsmålets form. Det er på denne måde Blanchot lader essayet undersøge litteraturens mulighedsbetingelse, idet spørgsmålet holdes åbent, og hensat i en sådan suspense hvor litteraturens mulige eksistens endnu aldrig er virkeliggjort kan skriftens bestemmelser kun henvise til et fravær. Dette fravær er konstitutivt i kunstværket, værket reflekterer sit eget manglende væsen, sit altid udsatte nærvær. Som konsekvens vil et sådant fravær i kunstværket heller ikke kunne rumme nogen ontologisk henvisningsfunktion, værkets eksistens er ikke eksistentielt bestemt, og dette forhold foranlediger Blanchot til at hævde eller bekræfte et fælleskab i den moderne litteratur omkring galskaben.

I forskellige essays henviser Blanchot til deSades, Hölderlins, Lautréaumonts og Nietzsches galskab, men understreger at denne galskab tilhører en ren litterær erfaring uden for modsætningen mellem fornuft og galskab. En sådan modsætning tilhører endnu en eksistentiel fornuftsorden der netop kun kan herske ved at skelne mellem sig selv og galskab, ved at attributere eksistensen fornuftens træk. Men skriven indstifter en galskab, en galskab båret af pathos, og ikke længere en galskab rejst af logos som modsætning til logos selv, hvilket gør den litterære erfarings galskab uforståelig for fornuften og altså i egentlig forstand patetisk. For at bestemme sig selv har logos måttet udgrænse alt det umage, andetheden, som da bestemmes som galskab, men den 
galskab Blanchot bekræfter er patetisk bundet til selve skrivehandlingen. Han citerer derfor flere gange Mallarmé for sætningen: „At skrive, dette meningsløse spil“ [Ecrire, ce jeu insensé]. Og derfor også denne hævdelse, i le Livre à venir, som på trods af sin ordlyd ikke skal opfattes som en generalitet: "Alle digtere siger det samme, hvilket imidlertid ikke er det samme, men det unikke vi føler" (p. 52). Det unikke er en singularitet, der undslipper modsætningen mellem enhed og generalitet, en samordning af galskab og værk som imidlertid bliver fraværende i kommentaren til værket. ${ }^{31}$

Det er på denne baggrund at det litterære sprog bliver at forstå som et fuldstændig upersonligt og neutralt sprog der taler, men taler før og efter sprogbrugeren så at sige træder op på dets strøm og aktualiserer det. Dette er neutralitetens tema hos Blanchot som han mest eksplicit har behandlet i essayet "Den narrative Stemme („,han“, det neutrale)". Dette "neutrale“ [neutre] må også forstås som "neutrum " hvor sproget hverken individueres $i$ han- eller hunkøn, og dette "han“ [le "ili"] burde måske ikke kun oversættes med "han" da det også betegner "det". Man kunne fristes til at parallellisere dette ",il" med det tyske "Es" $\mathrm{i}$ dets freudianske betydning, id'et, det ubevidste område af den menneskelige psyke, forudsat man forstår et sådant id som fuldstændig løsrevet fra ethvert menneskeligt perspektiv.

Spørgsmålet for Blanchot, sådan som det rejses i den moderne litteratur, bliver da: hvordan gør sproget opmærksom på individuationsformer der ikke er personlige, men finder sted som begivenheder? Gilles Deleuze har i forlængelse af Blanchots overvejelser foreslået et svar ved at kalde denne talende instans for fjerde person ental, for derved at komme ud over enhver psykologisk eller lingvistisk personalisme. Der er altså her tale om en udmatning af cogitoet til fordel for det præ-individuelle, de ikke-personlige individuationer, som udvekslingen mellem et Jeg og et Du ikke kan gøre rede for, idet en sådan udveksling altid vil være begrænset til ego'ets eller selv'ets personlige perspektiv.

Måske vi bedre kan genkende os selv eller anerkende vort fælleskab i de upersonlige begivenheder vi er fælles om at bekræfte 
eksistensen eller tilblivelsen af, end i Jegets diskurs hvor vi i en ren auto-affektion bestandig henvises til os selv, hvor det universelle Jeg henvises til det individuelle Mig. Det er i et sådant essentielt set dialogisk forhold til omverden vi må forstå Blanchots negative skrift: en skriven der ikke bliver til som min skrift, men bliver til som en begivenhed der gennem sin tilblivelse bekræfter min eksistens og min verden. Blanchots litteraturfilosofi må derfor nødvendigvis blive til i en ombrydning af den klassiske retorik, sådan som det har været forsøgt vist, for så vidt som denne netop søgte at skabe et perfekt, transitivt sprog der ikke står i vejen for budskabet, udvekslingen mellem et universelt Jeg og individuelt Mig eller Du. Det er en sådan ontologisk styring af sproget, som også lingvistikken og semiologien i det væsentligste tager udgangspunkt $i$, Blanchot søger at afspore med sin introduktion af et neutralt sprog.

Man kan så vende tilbage til problemet om Blanchots rent litterære erfaring og spørge om den rummer nogen form for etik. I den klassiske retorik behandles affekterne, dvs. ethos, som er grundlaget for etikken, og pathos under inventio. Men vi har set hvordan Blanchot, i forlængelse af Nietzsche og Mallarmé, netop forskyder inventio-begrebets status idet det for ham mindre drejer sig om at udfinde de rette tankefigurer, men i højere grad om at opfinde dem, eller genopfinde dem på ny, i en ny sammenhæng der var uforudselig i forhold til den intention, der oprindelig blev nedlagt i dem. Men hvis Blanchot har en etik, skal den uden tvivl findes i hans forståelse af læsningen. Det betyder, at etikken etableres ud fra en litterær eller kunstnerisk erfaring, ikke gennem imperativer nedlagt $\mathrm{i}$ teksten, men gennem læsningens aktualisering af den ethos og pathos som skriften er modtagelig for.

Ligesom skriften for Blanchot er en neutral, upersonlig frembringelse af betydning, trues læsningen af selve læserens person. Som det hedder i essayet „La communication" fra l'Espace littéraire:

Det der truer læsningen mest: læserens realitet, hans personlighed, hans ubeskedenhed, hans voldsomme iver efter i mødet med det han læser at 
forblive sig selv, og efter at være et menneske der generelt forstår at læse (p. 266).

Blanchot forstår på denne måde læsningen som en neutral, upersonlig aktivitet der adskiller sig fra forstäelsens aktivitet, idet forståelsen blot gør værket kommunikerbart og indskriver det $\mathrm{i}$ diskursernes fællesskab. Det læsningen erfarer i den moderne litteratur vil ifølge Blanchot være den pathos eller galskab der er forbundet med selve skrivehandlingen, men er forsvundet $i$ skriften og derfor udgør værkets fravær. Læsningen stifter altså bekendtskab med en intethed, artikuleret som neutralitet, men med den ublandede følelse af pathos.

Blanchots essayistik retter sig utrætteligt mod denne særegne litterære erfaring, og hans essays fremstår på den baggrund som et genuint udtryk for en særlige kritisk form der sætter den læser der underkaster sig og bekræfter den i en nødvendig forbindelse med en permanent krisetilstand. En sådan krise som litteraturen kaster os ud i beskriver han til sidst i en af de karakteristiske dialog-tekster fra l'Entretien infini kaldet "Voir, c'est ne pas parler", en krise der også er læserens ansvar og er en opfordring til læseren om at træde i dialog med litteraturen:

- Enhver undersøgelse er en krise. Det der søges er intet andet end søgningens eller undersøgelsens drejning, der lader krisen finde sted: den kritiske drejning.

- Det er håbløst abstrakt.

- Hvorfor? Jeg vil endda gå så vidt som til at sige, at ethvert vigtigt litterært værk netop er vigtigt, for så vidt som det mere direkte og mere rent sætter betydningen af denne drejning i værk; en drejning der, idet den kommer til syne, på besynderlig vis får værket til at svinge. Dette er et værk, hvori ikke-iværksættelsen, som dets altid decentrerede center, holder sig selv tilbage: værkets fravær.

- Værkets fravær som er et andet navn for galskab.

- Værkets fravær hvori diskursen ophører, så at skrivens bevægelse, uden for talen, uden for sproget, kan opstå, tiltrukket af det udenfor (p. $45)$. 


\section{Noter:}

1. Optrykt i Martin Heideggers Holzwege (Frankfurt: Vittorio Klostermann 1994), pp. 269-320. I Holzwege, oprindelig udkommet i 1950, er desuden optrykt Heideggers Ursprung des Kunstwerks der i tråd med Heideggers øvrige publikationer fra fyrrerne og halvtredserne har haft afgørende betydning for drejningen hos Blanchot fra et eksistentielt til et litterært erfaringsbegreb. For en kort videre redegørelse for sammenhængen mellem Blanchots litteraturfilosofi og Heidegger, cf. Frederik Tygstrups og min indledning til Maurice Blanchot: Orfeus' blik og andre essays (Kbh.: Gyldendal 1994). I øvrigt går Blanchots inspiration fra Heidegger formodentlig tilbage til tyverne hvor Blanchot, der så vidt vides er uddannet germanist, skulle have studeret hos Heidegger.

2. Således kommenteres spørgsmålet bl.a. i Jørn Erslev Andersens Poetik og fragment. Hölderlin-studier (Århus: Modtryk 1993), p. 212; cf. også pp. 49-50 for en diskussion af den "betrængte tids" forbindelse med en natlig erfaring, og af forskellene mellem Hölderlins digteriske og Hegels filosofiske anvendelse af metaforen "nat".

3. Maurice Blanchot: L'espace littéraire (Paris: Gallimard 1955), p. 259.

4. For en nærmere analyse af dette digt, cf. Jørn Erslev Andersen: op. cit., pp. 139-49. Cf. også afsnittet „III.1: Ord, som blomster - ikke-similær konjunktion“, især pp. 179-80 vedrørende Hölderlins „forskydnings- og skabelsespoetik, der vedblivende reflekterer sig selv som digterisk skabelse" i Guds fravær.

5. En dansk parallel til Hölderlins dilemma finder man fx i Jacobsens parodiske "Genrebillede", hvor en page forgæves og uinspireret digter på et elskovskvad, indtil han "satte fortvivlet saa Hornet for Mund, / knugede vredt sit Værge, / blæste saa sin Elskov ud / over alle Bjærge." Også Jacobsen sætter sine tekster i en fundamental spørgende modalitet, med stor effekt $i$ et digt som „Arabesk. Til en Haandtegning af Michel Angelo” kulminerende i spørgsmålet: „Er det din Tanke, høje Kvinde?", men på en intrikat måde i det sene digt fra ca. 1882, „Lad Vaaren komme". I dette lille arabesk-fragment udgør de første 10 verselinier en øjensynligt legende og let beskrivelse af et nært forestående forår, som digter-jeget byder velkomment, men derefter falder spørgsmålet: „Hvad gjør det mig?" dvs. hvad gør det mig at foråret har en egen evne og vilje til at lade spirring og grokraft komme til udfoldelse. Denne spaltning mellem en natur og et jeg, der forholder sig indifferente over for hinanden, foregribes allerede i første vers" „Lad Vaaren komme, mens den vil ...". Digtet slutter: „Mit Hjerte er ej Blomst, ej Blad, / og Vaaren gjør det ikke glad: / Det har sin egen, sære Vaar, // naar?" Det sidste spørgsmål: hvornår bryder mit forår igennem? markerer en radikal dissymmetri mellem spørgsmål. Hvor det første spørgsmål har status af et figureret, retorisk spørgsmål negativt vendt mod forårsidyllen, 
er det andet spørgsmål et anderledes åbent spørgsmål intimt forbundet med den nu metaforicerede vår. Den sidste vår er en slags absolut metafor, idet den gøres egen og sær, sær-egen, dvs. vristes fri fra sin similaritet med den første vår. Når der spørges til denne særegne vår, spørges der altså ikke længere til noget jeget kan sammenligne med eller spejle i omverden, og man kan sige at mens første spørgsmål markerer eksistentiel ligegyldighed, slår det andet spørgsmål om i en digterisk spør- . gen hvor symmetriske forskelle ophæves og hvor skriften åbner op for elementers flertydige gåen-over-i-hinanden.

6. Blanchot: op. cit., p. $185 /$ da. overs.: p. 115. Cf. hele dette afsnit om inspirationen delt op $\mathrm{i}$ tre essays, „Det udenfor, natten, „Orfeus' blik“ og "Inspirationen, manglen på inspiration".

7. Sofisten in Platons skrifter, udg. C. Høeg og H. Ræder (Kbh.: Reitzel 1939), bd. VII, p. 26.

8. Jacques Derrida: De l'esprit. Heidegger et la question (Paris: Galilée 1987), pp. 147-48. Cf. hele den lange note pp. 147-54 for en nøjere gennemgang af spørgsmålets status i Heideggers udredning af sprogets væsen, cf. også Heideggers "Das Wesen der Sprache", in Unterwegs zur Sprache (1959) (Tübingen: Neske 1986), p. 174 ff.

9. "L'avenir et la question de l'art", in L'espace littéraire, p. 220.

10. Anekdoten om Mallarmés henvisning til Orfeus som digtningens oprindelse gengives i Henri Mondors Vie de Mallarmé. Her fortælles hvordan Mallarmé i påsken 1894 i Valvins, hans hus syd for Paris, modtog besøg af de yngre digtere Henri de Régnier og Élémir Bourges: „Mallarmé lader dem, ved bordet, smage forskellige vine og en kirsch som han koketterende selv serverer. Han siger til dem: „Har poesien ikke godt og grundigt været på gale veje siden den store homeriske vildfarelse?" - „Hvad var der før Homer?" siger Bourges. - „Orfeus!"“", op. cit., (Paris: Gallimard 19412), p. 683.

11. Maurice Blanchot: op. cit., p. 260.

12. Die fröhliche Wissenschaft, in Werke, udg. K. Schlechta (Frankfurt/M: C. H. Verlag 1966), bd. II, §354, p. 223.

13. Jan Lindhardts definition på inventio i Retorik (Kbh.: Berlingske 1975), p. 51.

14. Aus dem Nachlass der Achtzigerjahre, in Werke, bd. III, p. 844.

15. Stéphane Mallarmé: „La musique et les lettres", in CEuvres complètes (Paris: Gallimard 1945), p. 643.

16. Op. cit. (Paris: Gallimard 1966), pp. 316-17.

17. Maurice Blanchot: op. cit., p. 18. Overalt hvor Blanchot i sine essays fra halvtredserne taler om at bekymre sig om noget eller drage omsorg for noget, må man påtænke den eksistentialistiske og fænomenologiske sammenhæng han skriver sig ind i. I disse tilfælde er det franske grundord souci, hvilket er oversættelsen af Heideggers begreb om Sorge, dvs. den optagethed der sammenfatter eksistentialerne, de eksistentielle 
grundtræk i tilværens væren, Dasein. Når Blanchot her taler om værkets ubekymrethed, skal det læses som udtryk for vendingen fra en eksistentiel erfaring til en litterær erfaring der udgør den centrale bevægelse i hans litteraturfilosofi. Værket er ubekymret om, uden omsorg for, ikke optaget af Dasein, men bevæger sig mod noget udenfor den eksistentielle erfarings grænser, noget der kun har skriften som mellemværende, værkets fravær.

18. Cf. Rudolphe Gasché: „Aristoteles' frembringelse af begrebet om litteratur i sin Poetik (i efterbyrden fra Platons bestemmelse af poesi som mimesis) indleder litteraturhistorien som en historie hvori litteraturens dåbsattest, deklarationen af dens navn, er sammenfaldende med litteraturens forsvinding. Litteratur, siger Jacques Derrida, blev født ud af den historie der varede indtil det nittende århundrede, og litteraturen døde af den historie", The Tain of the Mirror: Derrida and the Philosophy of Reflection (Cambridge, Mass. og London: Harvard U. P. 1986), p. 256.

19. Gilles Deleuze har i denne forbindelse opregnet tre reflektoriske omdrejningspunkter hvor Blanchot har haft en afgørende indflydelse på Foucault: „For det første at tale er ikke at se ...", denne forskel der gør at man, ved at sige det man ikke kan se, bringer sproget til sin yderste grænse, man ophøjer det til det usigeliges magt. Dernæst den tredje persons overlegenhed, "han" eller det neutrale, "man", i forhold til de to første personer, afvisningen af enhver lingvistisk personologi. Og endelig temaet omkring det Udenfor: forbindelsen, såvel som "ikkeforbindelsen", med et Udenfor, der er længere væk end enhver ydre verden, og på tilsvarende vis tættere på end enhver indre verden," Pourparles (Paris: Minuit 1990), p. 133.

20. Michel Foucault: La pensée du dehors (Paris: Fata Morgana 1986), pp. 12-13.

21. L'entretien infini, p. 239.

22. '„Udgiverens kommentar og noter", in Martin Heidegger: Hvad er metafysik? (Kbh.: Vinten 1973), p. 159.

23. Op. cit., p. 567/ p. 183. I essayet, "l' Athéisme et l'écriture. L'humanisme et le cri", også fra l'Entretien infini, opsummerer han denne kritik af fænomenologiens sprogopfattelse som båret af en sammenhæng mellem lys og mening: „Det er sandt at fænomenologien fastholder subjektets forrang: der findes en oprindelse. Denne oprindelse er lys, et altid mere oprindeligt lys fra et lysende første der får mindelsen om et meningens første lys til at skinne i enhver forstand [...]. Fænomenologien fuldender således den vestlige tankes enestående skæbne ifølge hvilken væren, viden (blik eller intuition) og logos bør betragtes som begrebsligt knyttet til lys. Det synlige, evidensen, forklaringen, idealiteten eller logikkens overlegne klarhed eller, ved en simpel omvending, det usynlige, det utydelige, det ulogiske eller den tavse aflejring: dette er variationer af Tilsynekomsten, af det første Fænomen. Og ud af dette får spro- 
get sit væsen. Sproghandlingen forbliver da udtryk: det drejer sig om at udtrykke den mening der altid går forud, for dernæst at bevare den så godt som muligt i dens lysende idealitet; eller, hvis den videnskabelige sandhed skal siges, for at konstituere sig selv ved at frigøre sig fra den psykologiske singularitet hos den der formodes at have frembragt den, og hvis sproget har en konstituerende evne, er det desuden nødvendigt straks at tilføje at det er det talende subjekt selv der besidder denne evne: ikke at talen derved optager subjektets sted i denne konstituerende handling (fænomenologisk set vil dette være skandaløst), men subjektet taler og man vil end ikke kunne sige i sin egenskab af subjekt, eftersom subjektiviteten i sig selv er tavs, overladt til modtagelsen af et sprog der er i stand til præcist at udtrykke den," op. cit., p. 375.

24. I denne skelnen mellem skriven og skrift er der i øvrigt en klar parallel mellem Blanchots litteraturfilosofi og Per Højholts poetik, Intethedens grimasser. Højholts litterære erfaringer kulminerer her med en redegørelse for hvilke konsekvenser det også for ham har været nødvendigt at drage af Mallarmés poetiske praksis, og i en ofte citeret passage skriver han bl.a.: "I stedet for, som før, at betragte og behandle det sproglige kunstværk som resultatet af en skriven der har kunstværket som mål, kan man opfatte det som skrift, dvs. som resterne af en skriven uden mål [...]. Teksten bliver altså „blot" det synlige spor af en skriven som ikke havde sporet som genstand," op. cit. (Herning: Schønberg 1972), p. 146. Cf. desuden Blanchot i "Bogens fravær": "Skriven har ikke sit mål i bogen eller i værket," l'Entretien infini, p. 624/p. 189.

25. G.W.F. Hegel: op. cit., in Werke (Frankfurt: Suhrkamp 1989), bd. III, p. 36/da. overs.: Hegel (Kbh.: Berlingske 1971), p. 155. Cf. P. Adams Sitneys diskussion af dette filosofiske lån i hans efterord til The Gaze of. Orpheus and other literary essays (New York: Station Hill 1981), pp. 178-80.

26. Stéphane Mallarmé: "Crise de vers", in CEuvres complètes, p. 368.

27. P. A. Sitney fastholder forbavsende nok i sit ellers glimrende efterord til The Gaze of Orpheus, at de forskellige figurer er allegorier og hævder, at „Blanchot insisterer på at de mest sublime historier, vore centrale myter, er allegorier på de tekstuelle konfrontationer vi er besat af at undgå. [...] Blanchots bugtede stil indbyder læseren til at deltage i en begivenhed der gør disse allegorier til ritualer. Han negligerer desuden gyldigheden af allegoriens modalitet idet han foretrækker at genintroducere den romantiske teori om "symbolet", op. cit., p. 171.

28. Fontanier: Les figures $d u$ discours (1821-30) (Paris: Flammarion 1977), p. 114.

29. Op. cit. (Paris: Gallimard 1959), pp. 12-15/pp. 133-38.

30. Fontanier: op. cit., p. 116.

31. Denne kommentar til Blanchots litteraturfilosofi, hans værk, er naturligvis underlagt samme betingelser og ude af stand til at fremstille værkets fravær. En kommentar der mere autentisk skulle gøre sig håb 
om at indskrive galskaben i sin ræsonnerende diskurs måtte, hinsides denne kommentars omstændelige fremfærd, reflekterer bestemmelsen af litteraturens spørgen i en langt mere åbnende form. 